\title{
Partial Extraction Therapy -A Review
}

Dr. Parvez Abubakar ${ }^{1 *}$, Dr. Sharnabasappa C Nagaral ${ }^{2}$, Dr. Lijeena Ann Benji ${ }^{3}$, Dr. Siddhant Vilas Dandawate ${ }^{3}$, Dr. Pavan Kamalapurkar ${ }^{4}$, Dr. Tanveer Fatima ${ }^{1}$

${ }^{1}$ Reader, Department Of Prosthodontics, Al Badar Rural Dental College and Hospital, Opp. Koranti Hanuman Temple, Naganahalli Road, Kalaburagi 585102, India

${ }^{2}$ Professor and Hod, Department Of Prosthodontics, Al Badar Rural Dental College And Hospital, Opp. Koranti Hanuman Temple, Naganahalli Road, Kalaburagi - 585102, India

${ }^{3}$ Postgraduate Student, Department Of Prosthodontics, Al Badar Rural Dental College And Hospital, Opp. Koranti Hanuman Temple, Naganahalli Road, Kalaburagi -585102 , India

${ }^{4}$ Professor, Department Of Prosthodontics, Al Badar Rural Dental College And Hospital, Opp. Koranti Hanuman Temple, Naganahalli Road, Kalaburagi - 585102, India

DOI: $10.36347 /$ sjds.2021.v08i04.001

| Received: 09.02.2021 | Accepted: 15.04.2021 | Published: 18.04.2021

*Corresponding author: Dr. Parvez Abubakar

\section{Abstract}

The bone loss following an extraction is inevitable. The buccopalatal collapse due to horizontal and vertical bone loss can cause unesthetic appearance following a prosthesis on a long run. The partial extraction therapy involves a group of procedures to preserve buccopalatal bone thereby preserving the bone and improving esthetic.

Keywords: Partial extraction therapy, Bundle bone-periodontal ligament complex, Socket shield technique.

Copyright $\left({ }_{0} 2021\right.$ The Author(s): This is an open-access article distributed under the terms of the Creative Commons Attribution 4.0 International License (CC BY-NC 4.0) which permits unrestricted use, distribution, and reproduction in any medium for non-commercial use provided the original author and source are credited.

\section{INTRODUCTION}

Ridge resorption because of tooth loss is all around revealed in the literature [1]. This deficiency of alveolar bone and change in ridge shape is the aftereffect of the bundle bone-periodontal ligament (BB-PDL) complex lost after the expulsion of a tooth $[2,3]$ partial extraction therapies (PET) address a subgroup of precollapse interventions that on the whole utilize the actual tooth to counterbalance the deficiency of alveolar tissue by holding the tooth root and its attachment to bone, the BB-PDL complex with its vascular supply may be kept up.

\section{SOCKET-SHIELD TECHNIQUE}

Socket shield technique was introduced by Hürzeler et al., The principle of socket shield technique is to preserve the root of a tooth indicated for extraction thereby preserving the buccal/facial root section and its bundle bone - periodontal complex so as to prevent resorption of the ridge and to support the buccal / facial tissues $[7,8]$.

\section{INDICATIONS}

- Tooth crown which cannot be restored or tooth indicated for extraction

- Tooth root with or without apical pathology

- Immediate implant placement

- Ridge preservation in conjunction with other PET

\section{ARMAMENTARIUM}

1. Socket-shield

2. Long shank root resection bur

3. Extra-large round diamond head bur

4. End-cutting diamond head bur

5. Gingival protector

6. Irrigated surgical motor

7. Contra-angled surgical fast handpiece

8. Microperiotomes

9. Microforceps

\section{PROCEDURE}

- The tooth indicated for socket shield technique is decoronated till gingival level following adequate local anaesthetia.

- An irrigated long-shank surgical root resection bur is used to section the root mesiodistally and longitudinally midway through with the canal as a reference point, such that both labial and palatal halves are separated from the coronal to the apical aspect.

- A microperiotome instrument is inserted into the palatal PDL space, carefully displacing the palatal root section labially into the recess created by the sectioning bur and microforceps is used to retrive it.

- The labial root section which remains inside the socket is instrumented on its inner aspect with a sharp probe, for immobility. 
- An irrigated large round diamond bur is used to reduce the coronal aspect of the root section $1 \mathrm{~mm}$ above the alveolar socket crest and shaped as a crescent shaped concavity following the contour of the alveolus.

- The implant is then immediately placed palatal to the socket shield.

The space between the implant and the alveolar socket wall, is termed as buccal gap. Baumer et $a l$., demonstrated the formation of new bone between the implant and the dentin surface.

\section{CLASSIFICATION}

Depending on the position of the shield in the socket $^{7}$, SST is classified into-

\section{Type I: Buccal shield}

The shield lies only in buccal part of the socket, It is mostly indicated in single edentulous site with both teeth present adjacent to it.

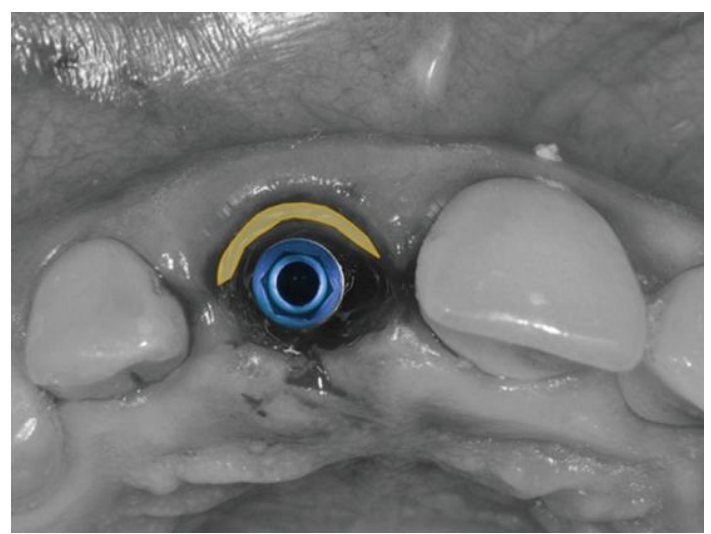

Type I: Buccal shield

\section{Type II - Full C buccal shield}

The shield lies in buccal part and the interproximal part on both sides of the socket. It is indicated in existing implant on either side of the proposed site. Missing tooth on either side without an implant, having implant on one side and missing tooth on the other side.

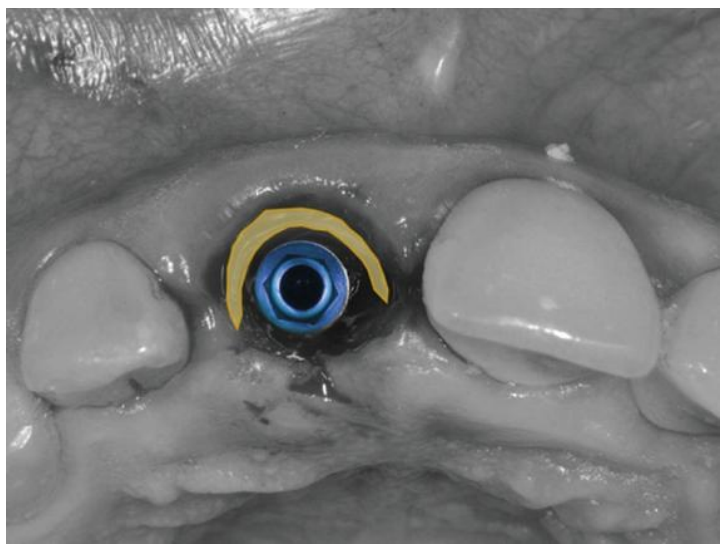

Type II: Full C buccal shield
Type III: Half C buccal shield

In this technique shield is preserved in buccal part and one of the interproximal part. This is indicated when there is tooth on one side and implant or a missing tooth on the other side.

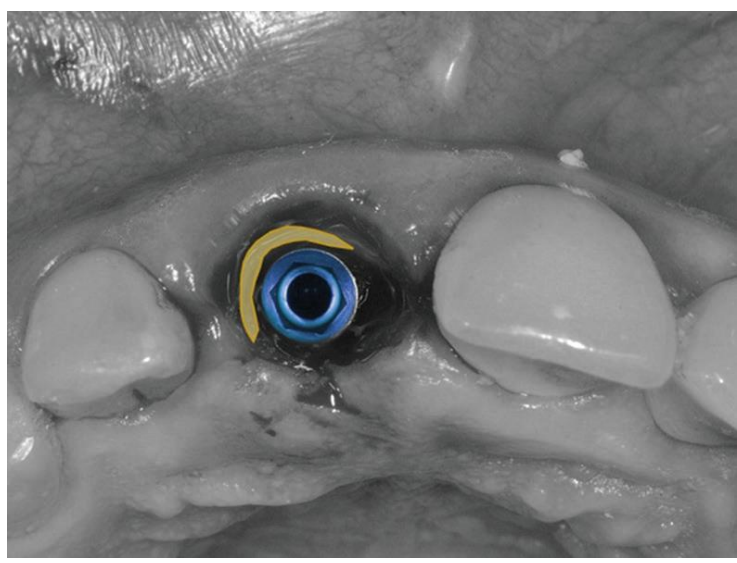

Type III: Half C buccal shield

Type IV: Interproximal shield

Here the shield lies only in mesial or distal part of the socket.

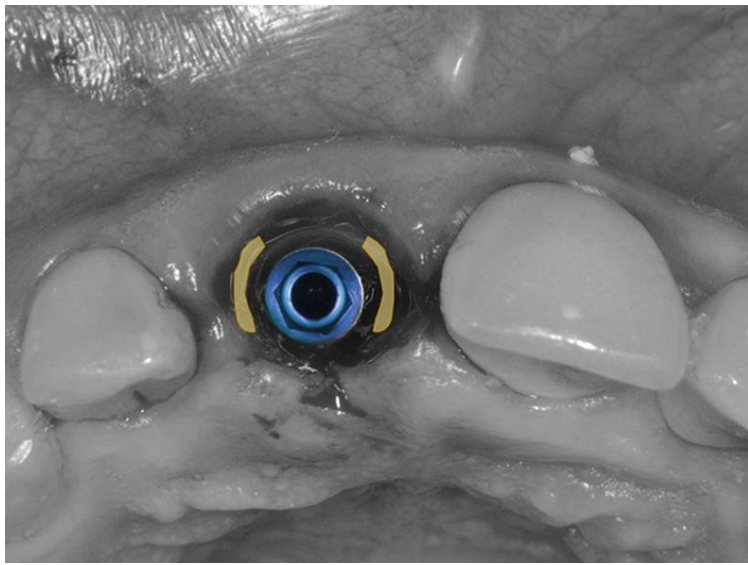

Type IV: Interproximal shield

Type V: Lingual-palatal shield

The shield lies on the palatal or lingual side of the socket.

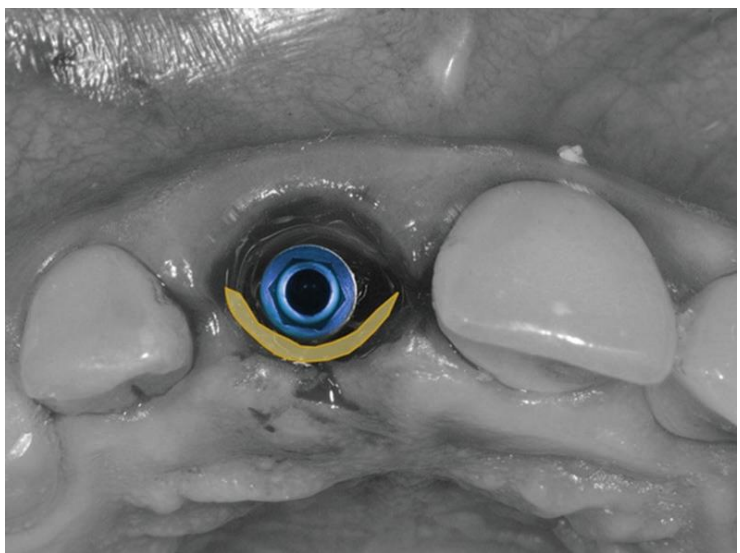

Type V: Lingual-palatal shield 
Type VI: Multiple buccal shields

Here it has two or more shield in the socket. It is recommended in cases with a vertical root fracture.

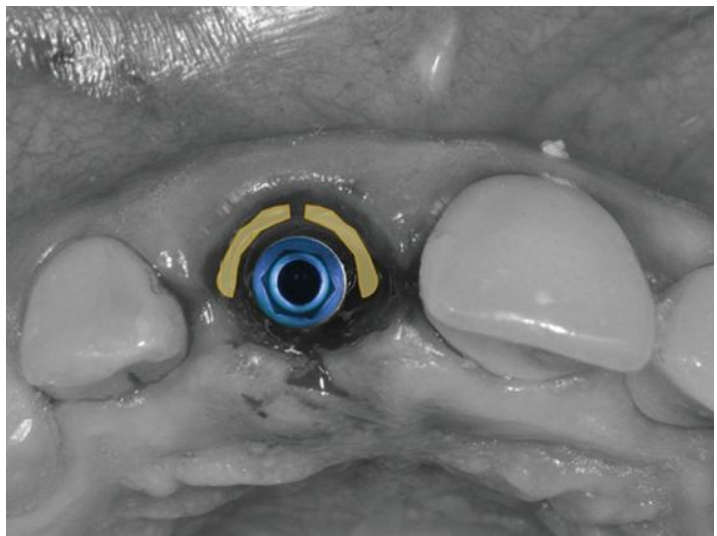

Type VI: Multiple buccal shields

\section{ADVANTAGES}

- It helps in maintaining a part of the root to preserve hard and soft-tissue contours.

- It minimizes the need of grafting procedures and thereby shortens treatment duration.

- The interdental papilla can be also preserved by preparing interdental socket shield for adjacent implant cases.

- It helps in maintaining pink and white esthetics.

\section{LIMITATIONS}

- Highly Technique sensitive.

- If the shield becomes mobile during surgery, it is removed, and the conventional immediate implant placement is preferred.

- The case selection is very important.

- It is not recommended in teeth that are mobile, out of the arch and with large periapical lesions.

\section{PONTIC SHIELD TECHNIQUE}

This technique involves similar preparation to the SST and followed by grafting the socket with slowresorbing bone substitute material. A minimum healing period of 3 months is required and later pontic pressure may gradually be applied to develop the site. This technique is indicated in sites planned to receive a pontic restoration as removable partial denture or a tooth-supported or implant-supported fixed partial denture $[5,6]$.

\section{INDICATIONS}

- Tooth crown that cannot be restored or tooth indicated for extraction.

- Tooth root with or without apical pathology.

- Planned pontic site(s) beneath fixed prosthesis.

- Cantilever pontic site as an alternative to two adjacent implants.
ARMAMENTARIUM

1. Long shank root resection bur

2. Extra-large round diamond head bur

3. End-cutting diamond head bur

4. Gingival protector

5. Irrigated surgical motor

6. Contra-angled surgical fast handpiece

7. Microperiotomes

8. Microforceps

9. Socket grafting instruments: plugger, particulate graft spoon, crucible

10. SM 69 blade

11. $6 / 0$ nylon sutures

\section{TECHNIQUE}

- This technique combines the socket-shield technique with grafting treatments.

- The socket-shield is prepared first.

- After preparation similar to SST, the socket is curettaged along with copious saline rinse.

- Then the socket is grafted with bone particulate or a bone substitute material. The material should not be densely packed with excessive pressure and care is taken not to disturb the shield.

- Once the socket is adequately filled, it must be sealed.

- The authors recommend an autogenous connective tissue graft (CTG) or rotated pedicle flap or dense polytetrafluoroethylene(dptfe) membrane.

- A provisional restoration with light pontic pressure is fixed in place for the duration of healing.

\section{ROOT SUBMERGENCE TECHNIQUE INTRODUCTION}

The root submergence technique or the root banking was introduced in the 1950s in prosthodontics to maintain the alveolar ridge under complete dentures. Root submergence technique involves decoronation of the tooth crown and preserving the intact root. Dental pulps can be vitally preserved or endodontic treatment can be performed before or during the procedure. Here the tooth is reduced to $2 \mathrm{~mm}$ below the free gingival margin to make it at the level of the alveolar crest and the socket is left for 3 to 4 weeks so that surrounding tissue can proliferate over the remaining root $[5,6]$.

\section{INDICATIONS}

- In cases where tooth cannot be restored or indicated for extraction

- With no apical pathology

- Healthy amputated pulp or endodontic therapy completed

- Indicated for removable full or partial prosthesis or beneath fixed prosthesis 
Parvez Abubakar et al., Sch J Dent Sci, Apr, 2021; 8(4): 107-110

\section{ARMAMENTARIUM}

1. Irrigated surgical motor

2. Contra-angled handpiece

3. Large round diamond head bur

4. Sm 69 blade

$5.6 / 0$ nylon suture

\section{TECHNIQUE}

- This technique involves preparation of the root slightly below bone level to protect the soft tissue from perforation.

- The root is shaped to form a concavity that will allow soft tissue infill that when healed using with an irrigated large diamond bur.

- The authors recommend that coverage of the coronal root is mandatory: by CTG for a single tooth site, and by primary intention approximation of the flap.

- Healing period minimum of 3 months is required before applying any pontic pressure.

\section{CONCLUSION}

Bone resorption following an extraction is inevitable. Atraumatic extraction of a tooth with immediate implant placement also showed loss of buccal bone. The loss of supporting bone resulted in the apical migration of soft tissue resulting in black triangles between teeth. Partial extraction therapies (PET) involves a group of precollapse interventions that on the whole utilize the actual tooth to counterbalance the deficiency of alveolar tissue by holding the tooth root and its attachment to bone, the BB-PDL complex with its vascular supply may be kept up. More long term studies are required to know whether pressure can be applied and tolerated at the pontic site in less than 3 months keeping in view how the soft tissue and bone will react to forces under different variables of systemic and local factors.

\section{REFERENCES}

1. Van der Weijden F, Dell'Acqua F, Slot DE. Alveolar bone dimensional changes of postextraction sockets in humans: a systematic review. Journal of clinical periodontology. 2009 Dec;36(12):1048-58.

2. Araújo MG, SukekavaF, Wennström JL, Lindhe J. Ridge alterations following implant placement in fresh extraction sockets: An experimental study in the dog. J Clin Periodontol. 2005;32:645-652.

3. Cardaropoli G, Araújo M, Lindhe J. Dynamics of bone tissue formation in tooth extraction sites. An experimental study in dogs. J Clin Periodontol. 2003;30: 809-818.

4. Gluckman H, Salama M, Du Toit J. Partial Extraction Therapies (PET) Part 1: Maintaining Alveolar Ridge Contour at Pontic andImmediate Implant Sites. Int J Periodontics Restorative Dent. 2016 Sep-Oct;36(5):681-7.

5. Gluckman H, Salama M, Du Toit J. Partial Extraction Therapies (PET) Part 2: Procedures and Technical Aspects. Int J Periodontics Restorative Dent. 2017 May/Jun;37(3):377-385.

6. Gluckman H, Du Toit J, Salama M. The pontic shield: Partial extraction therapy for ridge preservation and pontic site development. Int $\mathrm{J}$ Periodontics Restorative Dent. 2016:36;417-423.

7. Kumar PR, Kher U. Shield the socket: Procedure, case report andclassification. J Indian Soc Periodontol. 2018 May-Jun;22(3):266-272.

8. Hürzeler MB, Zuhr O, Schupbach P, Rebele SF, Emmanouilidis N, Fickl S. The socket- shield technique: A proof-of-principle report. J Clin Periodontol. 2010;37:855-862. 